\title{
Modeling of Vertical Greenery System As Passive Design Strategy for Mitigating Indoor Temperature
}

\author{
Ratih Widiastuti ${ }^{1}$, Bangun I.R.H. ${ }^{2}$, Hana Faza R.S. ${ }^{2}$, Chely Novia B. ${ }^{1}$, Bintang \\ Noor Prabowo ${ }^{1}$, and Mirza Ramandhika ${ }^{1}$ \\ ${ }^{1}$ Architectural Design, Vocational School, Diponegoro University, Semarang, Indonesia \\ ${ }^{2}$ Architecture Department, Engineering Faculty, Diponegoro University, Semarang, Indonesia
}

\section{Abstract}

The rapid development in developing countries causes decreasing in the green area which leads to the environmental problem. Increasing heat transfer in the building envelope push more energy, especially for air conditioning. Although vertical greenery system is not a new concept, however, the building planners do not use it as one of an alternative design for energy saving yet. This paper will present a study on the office building with vertical greenery system as a building envelope in the tropical

Corresponding Author: Ratih Widiastuti

ratihw@arsitektur.undip.ac.id

Received: 24 May 2019

Accepted: 25 July 2019

Published: 4 August 2019

Publishing services provided by Knowledge E

(c) Ratih Widiastuti et al. This article is distributed under the terms of the Creative Commons Attribution License, which permits unrestricted use and redistribution provided that the original author and source are credited.

Selection and Peer-review under the responsibility of the ISTEcS 2019 Conference Committee.

\section{G OPEN ACCESS} area, Indonesia. Data collection was done during summer time, in October 2013. There is two data analysis, based on the field measurement and Ecotect simulation. The result indicates that during data measurement at 05.00 a.m - 06.00 p.m. chamber with vertical greenery system has cooler surface temperatures and smaller in heat transfer. The peak temperatures of the exterior and interior facade with vertical greenery system are $29.13^{\circ} \mathrm{C}$ and $25.41^{\circ} \mathrm{C}$, respectively. While for bare wall facade are $32.30^{\circ} \mathrm{C}$ for exterior facade and $30.79^{\circ} \mathrm{C}$ for the interior facade. The results from the study proved that applying vertical greenery system on the building facade can reduce the heat transfer from the exterior facade to the interior facade

Keywords: building envelope, Ecotect simulation, surface temperature, vertical greenery system

\section{Introduction}

Studies in urban climatology highlighted the variety of urban surface covering material related to the energy balanced, both for macro and micro scale. The increasing of building densities resulting in the higher temperatures in the urban area that leads to Urban Heat Island (UHI) phenomenon [1-3]. It can be seen that the less greenery aspect in the city, the demand for HVAC system will increase, especially in the hot-humid climate area. In the other hand, most of the countries in the world, expected building to realize energy efficiency through active or passive design strategies. Because the 
biggest percentage of energy consumption for any building in a hot-humid climate is for air conditioning followed by artificial lighting [4].

Utilize the building facade area, vertical greenery system can be applied in the whole building envelope of multi-story buildings to alter the microclimate problem around the built environment [5]. Especially in dense urban area, where the area of the wall of the high rise building promising a large portion for greenery area compare to ground area and create potential benefits for cooling down the city scale [6, 7]. Further information said that the large surface of the green facade could improve air quality, urban biodiversity, and mitigation the effects of urban heat island [8-10].

Among the most important factors of vertical greenery, the system is the ability to shade the building facade from direct solar radiation that affecting the thermal performance of the building. It leads to the external surface temperature reduction and consequently reduces cooling energy consumption. Furthermore, the heat transfer mechanism on the facade with the vertical greenery system is different from the bare wall, due to the interposition of the foliage between the outdoor environment and the building envelope [11]. The outer layers of the foliage cover act like optical filters, while the deeper layers act like insulation [12].

Numerous studies proved the ability of vertical greenery system to minimize energy consumption in a building. First, a study conducted by [13], said that external shading devices could either be made of building materials or living plants and could reduce the indoor cooling load by $30 \%$ compared to the use of high-performance glazing [14]. A study in Penang also proved a reduction up to $6.4^{\circ} \mathrm{C}$ for the facade with vertical greenery system [15]. Another study conducted by Widiastuti et al. [16], explained that longer thermal lag found in the facade covered by vertical garden and beneficial to reduce cooling load during peak time.

The present paper aims to study the benefits of vertical greenery system as passive design strategy based on the Ecotect simulation. Data measurement conducted from one of the government buildings, PT. Pertamina located in Semarang City. The significance of this research is to understand how the vertical greenery system can contribute to lessening the cooling energy consumption.

\section{Research Method}




\subsection{Objek study}

The investigation was conducted in Semarang city located at 6 $6^{\circ} 58^{\prime} 43.000^{\prime \prime} S$ and $110^{\circ} 24^{\prime} 59.522$ "E using one of the facades in the building of PT. Pertamina can be seen in Fig. 1. Data measurement conducted during summer time. The weather condition is hot and humid with an average temperature of $28,8^{\circ} \mathrm{C}$. The lowest temperature recorded at $26.6^{\circ} \mathrm{C}$ while the highest temperature at $29,5^{\circ} \mathrm{C}$. The average humidity is relatively high at $62.3 \%$. It varies between $44 \%$ to $70 \%$. The wind is dry and hot with the average wind speed varies from $4.7 \mathrm{~m} / \mathrm{s}-7.6 \mathrm{~m} / \mathrm{s}$ [17].

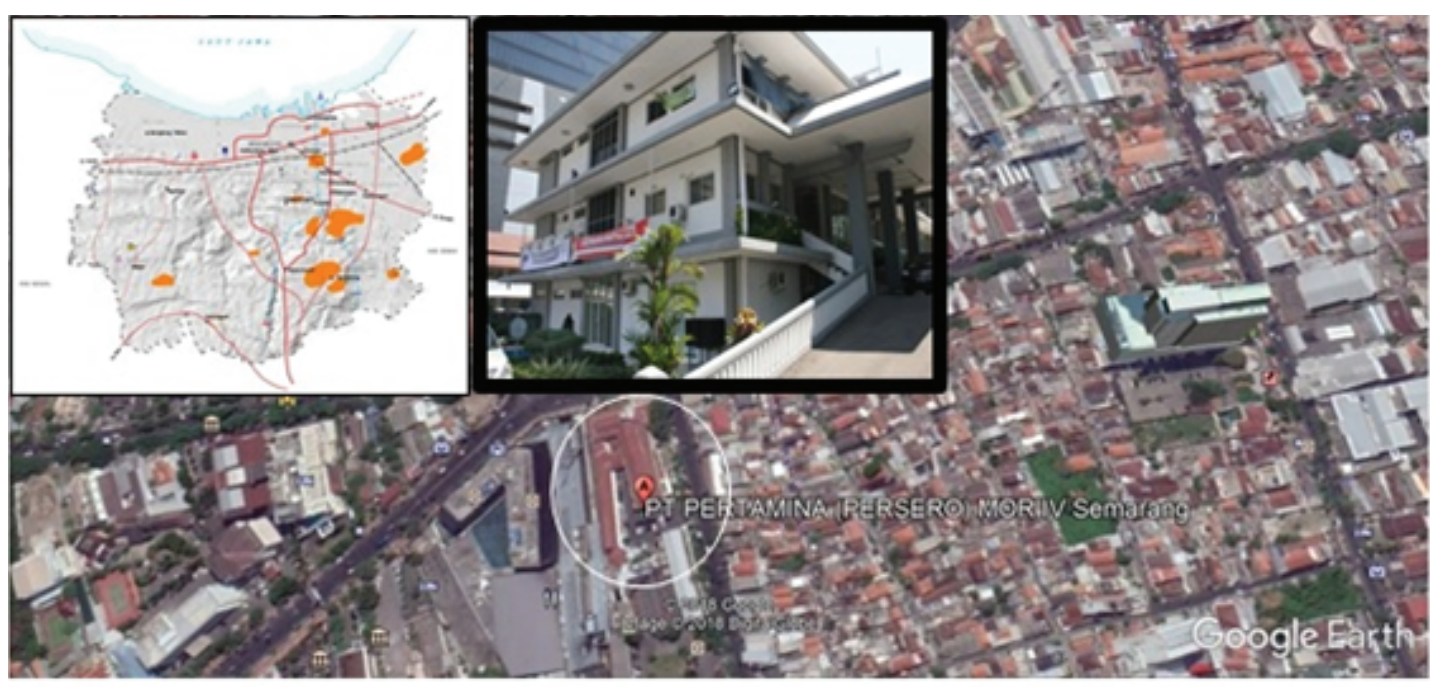

Figure 1: Location of data measurement, the office of PT. Pertamina $[18,19]$.

The kind of vertical greenery system is using a geo-textile system that consists of an aluminum structure, a PVC panel and felt layers [16], can be seen in Fig.3. Based on the observation, the plants are growing in the plant pockets which are always irrigated. Plants selection used small shrubs that placed in plant pockets with automatic watering system. At the top and side of the vertical garden is a flexible pipe for the irrigation. The water flow through the nozzle and the distance between each nozzle is $15 \mathrm{~mm}$. In this study, the vertical greenery system is installed on an external not insulated wall on the second floor.

This paper employs the quantitative approach for data collection through Ecotect simulation. This program was developed by Dr. Andrew Marsh and Square One Research Ltd. that was acquired by Autodesk [20]. The Ecotect analysis offers a wide range of simulation and building energy analysis functionalities to visualize and simulate a building's performance within the context of its environment [21]. The program can be used to create analysis model from scratch or to expand it from the imported data 


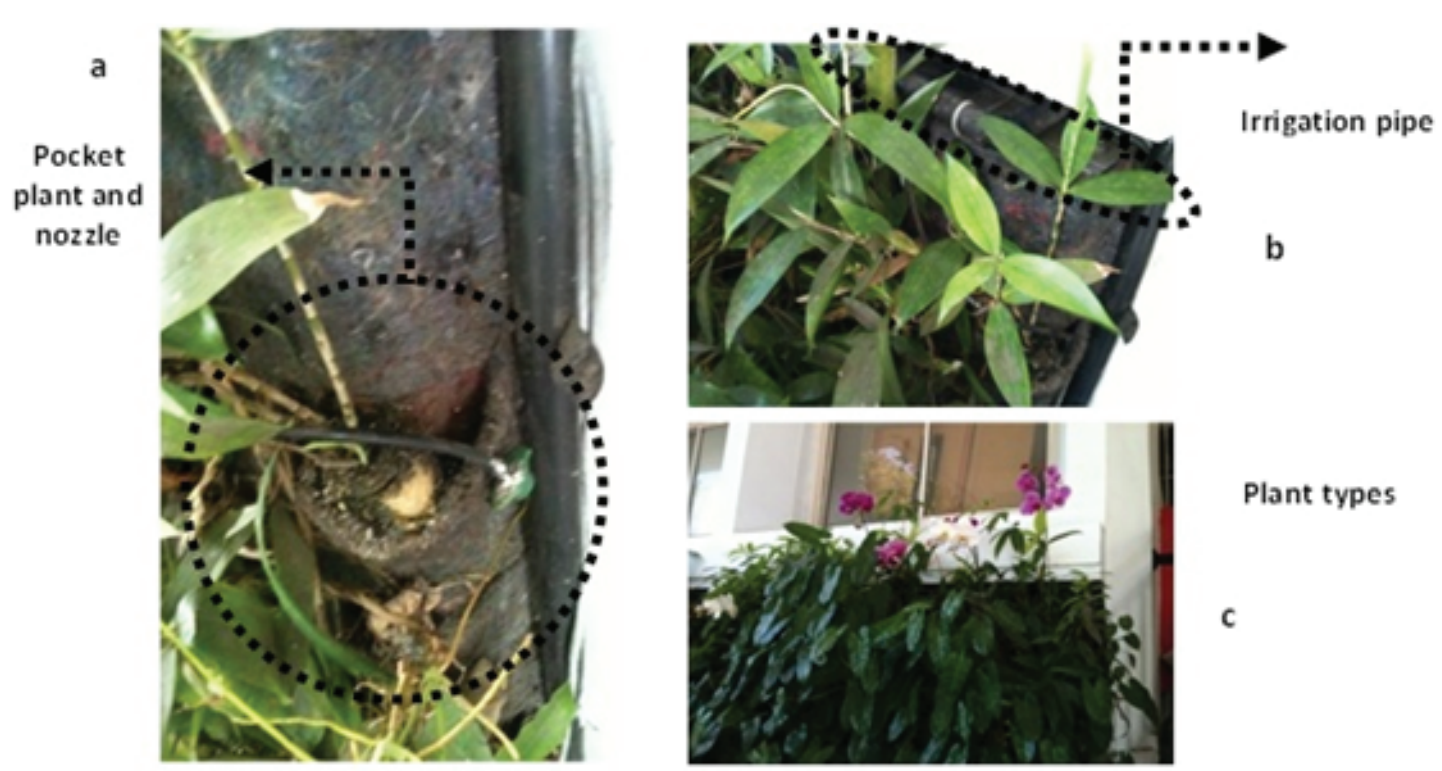

Figure 2: Detail of vertical garden model (a). Pocket plant and nozzle; (b). Irrigation pipe; (c). Types of the plant in the vertical garden model [16].

and also can perform a large number of specific types of thermal, solar, lighting and acoustical analysis [22].

The previous study conducted by Yin et al. [23] simulated a renovation of the existing building using Ecotect. In this study, two aspects are mentioned, building envelope material and indoor loads. The U-value as thermal resistance was used for steadystate on the modeling/calculation. The U-value divided into old material and new material for renovation suggestion. The old materials are u-value for existing brick walls $\left(1.232 \mathrm{~W} / \mathrm{m}^{2} \mathrm{~K}\right)$, non-insulated roof $\left(3.3775 \mathrm{~W} / \mathrm{m}^{2} \mathrm{~K}\right)$ and old single glazed-window (5.5617 $\left.\mathrm{W} / \mathrm{m}^{2} \mathrm{~K}\right)$. While for new materials, change old single glazed-window to be Low-Emissivity (Low-E) double glazing. The conduction heat losses reduce around $2.867 \mathrm{kWh}-2.607$ kWh. Furthermore, insulation materials were used to external walls that made the conduction heat losses reduced around $2.867 \mathrm{kWh}$ to $2.635 \mathrm{kWh}$. The result from Ecotect simulation proved that building energy consumption can be reduced almost $38.387 \mathrm{kWh}$ if existing building material changes into new materials that have good insulation.

\subsection{Method}

Fig. 3 provides the steps of the method in this study. The measurement of the following variables was done to make sure that the results are accurate and reliable on all categories: 
1. Exterior and interior surface temperature

2. Exterior and interior space temperature

3. Exterior and interior humidity

4. Wind speed

The dependent variables are the temperatures and the humidities. The efficiency of the vertical greenery system was determined according to their capability to reduce the cooling load of the building in comparison with the bare wall condition. The less energy needed to reduce the cooling load indicates the more efficient vertical greenery system.

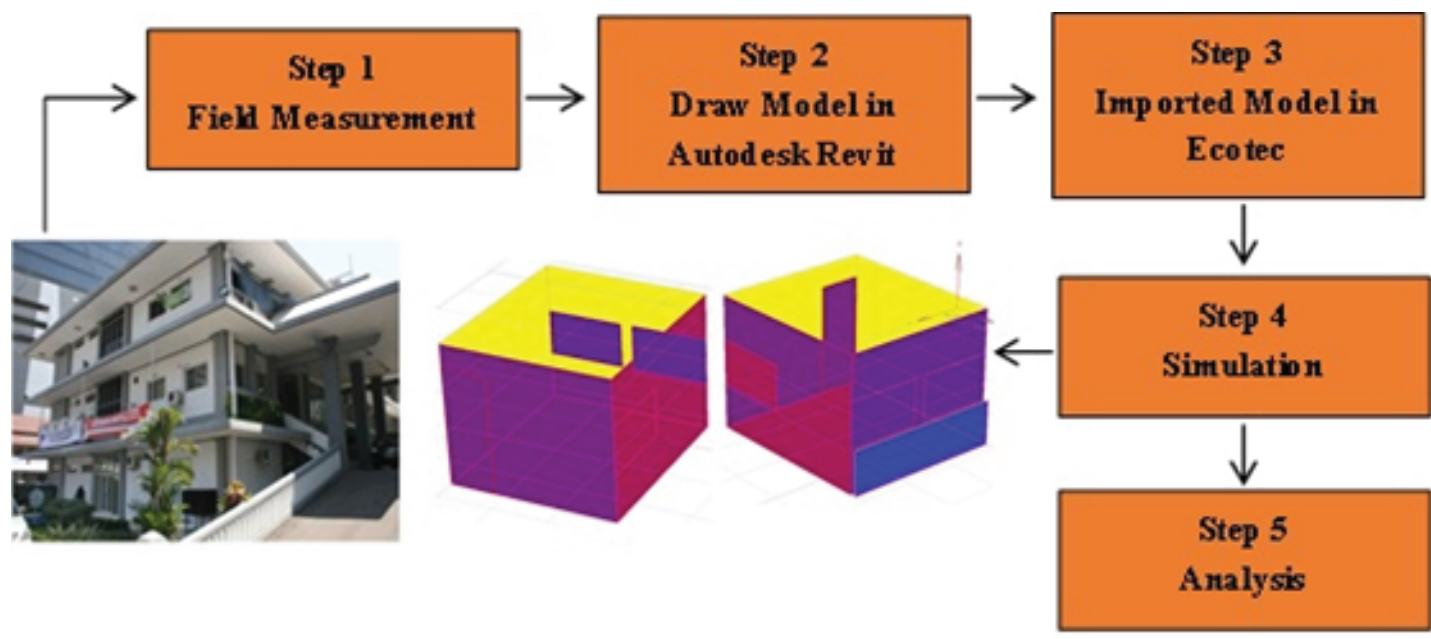

Figure 3: Workflow of research method in the study.

The object study selected for the simulation is a three stories office building located in Semarang City [16]. The illustration can be seen in Fig. 4. A chamber in the second floor used as a room with vertical greenery system and a chamber in the third floor used as data measurement for bare wall model. The condition of the multi-story building made the data related to wind speed difference between the second floor and third floor. Possibility, the result will be different. Therefore, due to the dissimilar condition, it is very unsafe to compare results directly. The chambers are equipped with windows in the front and sides. However, during data measurement, the windows always closed. While the vertical greenery system was using various types of plants as greenery elements such as Phalaenopsis sp., Dracaena warneckii and some of the local climber plants, can be seen in Fig. $\mathbf{5}$.

In this study, some of the measurement tools were used, like the following:

1. Hygro thermometers are used to measure air temperatures and air humidities on the exterior and interior space placed at the middle of the chamber. 


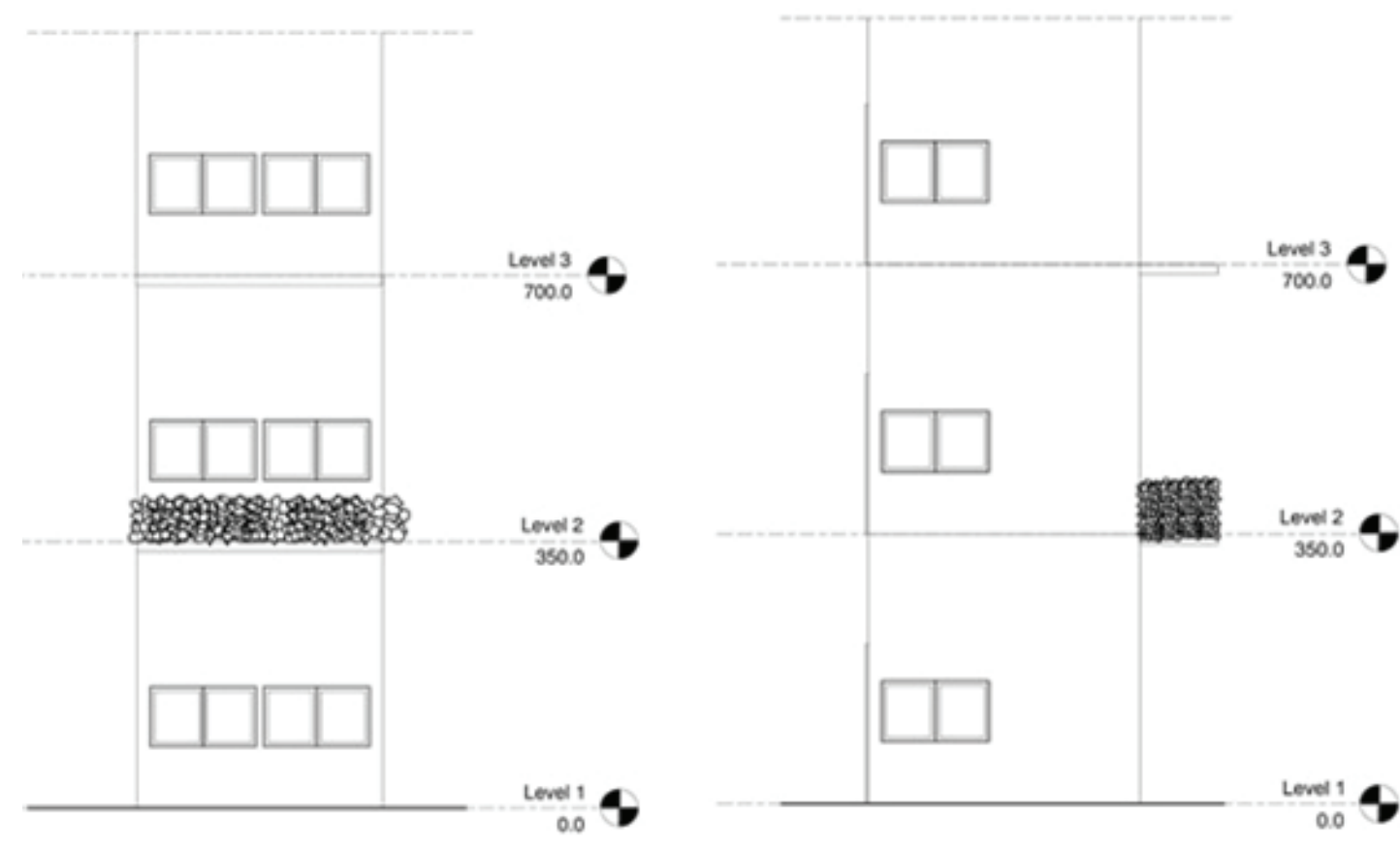

Figure 4: Schematic representation of the object for data measurement.

2. 4 In 1 Environment Tester LM-8000 to measure wind speed near the facade at a distance $50 \mathrm{~cm}$.

3. Infrared-surface thermometer to measure the exterior and interior surface temperatures. To collect the accurate data, the facades surface, both exterior and interior of chambers are divided into twenty-one measurement points. They are seven on the bottom, seven on the middle and seven on the bottom. The data of surface temperature are the average from the twenty-one measurement points.

While for data collected was done at 1-hour interval and the illustration of measurement points can be seen in Fig. 6 .

\subsection{Ecotect simulation}

To determine the effectiveness of the vertical greenery system, a strategy was introduced based on Ecotect simulations to gather accurate value of heat transfer performance on the object study. In this study, Ecotect program is used for analysis at the stage of conceptual design (initial design). However, it also can be used for analysis at the development stage of the building.

The simulation process involves the application of several steps as described in Fig. 3 to ensure that the process is clearly well thought and reliable results can be achieved. The details of the process of simulations follow: 


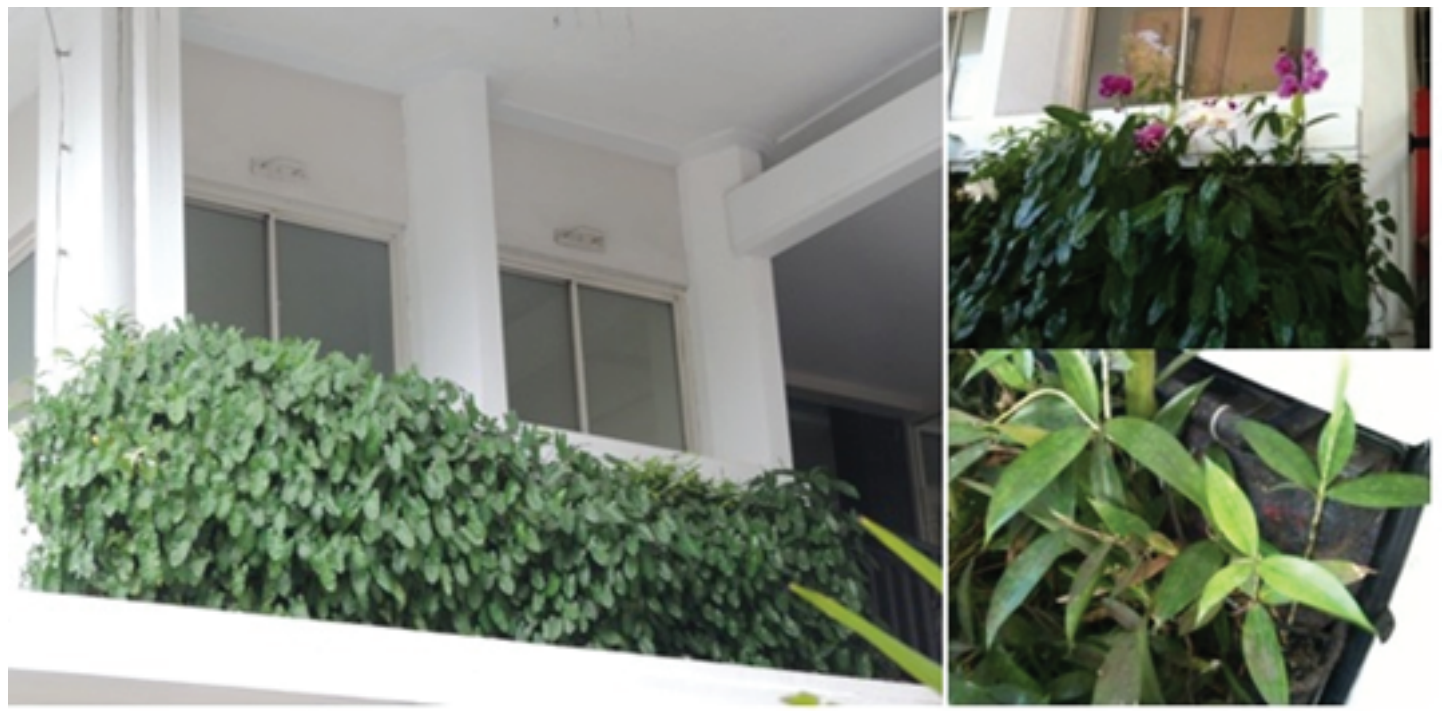

Figure 5: Application of vertical greenery system in object measurement [13].
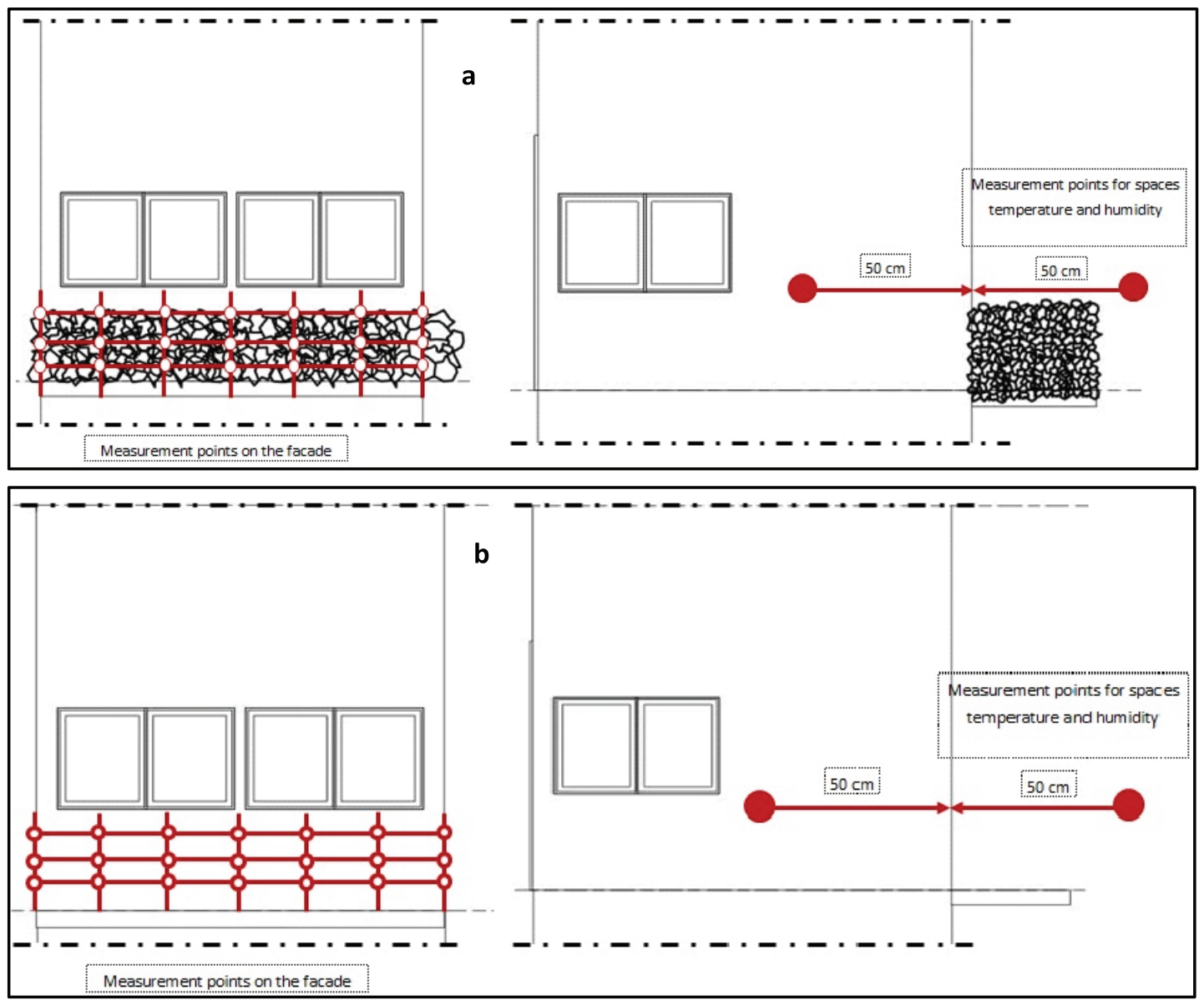

Figure 6: The illustration of measurement points (a). Chamber with vertical greenery; (b). Chamber with bare walls.

1. Draw model of the chamber, which includes the floor plans, elevation, and section in the scale of 1:50 using Autodesk Revit. The total floor area for each chamber 
is $9.9 \mathrm{~m}^{2}$. There is two models of chamber, first for chamber with bare wall and another one is a chamber with the vertical greenery system, can be seen in Fig. 7.

2. Import the 3D model in Ecotect. Choose the orientation, location, date and weather data. The orientation of the building is east, and the building is located in Semarang City.

3. Choose the building materials from the library or add materials. These materials must be constant for all simulation since different types of material might affect the results. For the model with vertical greenery system, the chosen material was equal with material that has characteristic the same as a plant.

4. Simulate energy efficiency based on the data measurement of the chamber without vertical greenery system. Record the result.

5. Apply the second type of chamber and record the results.

6. Discuss and analyze the results.

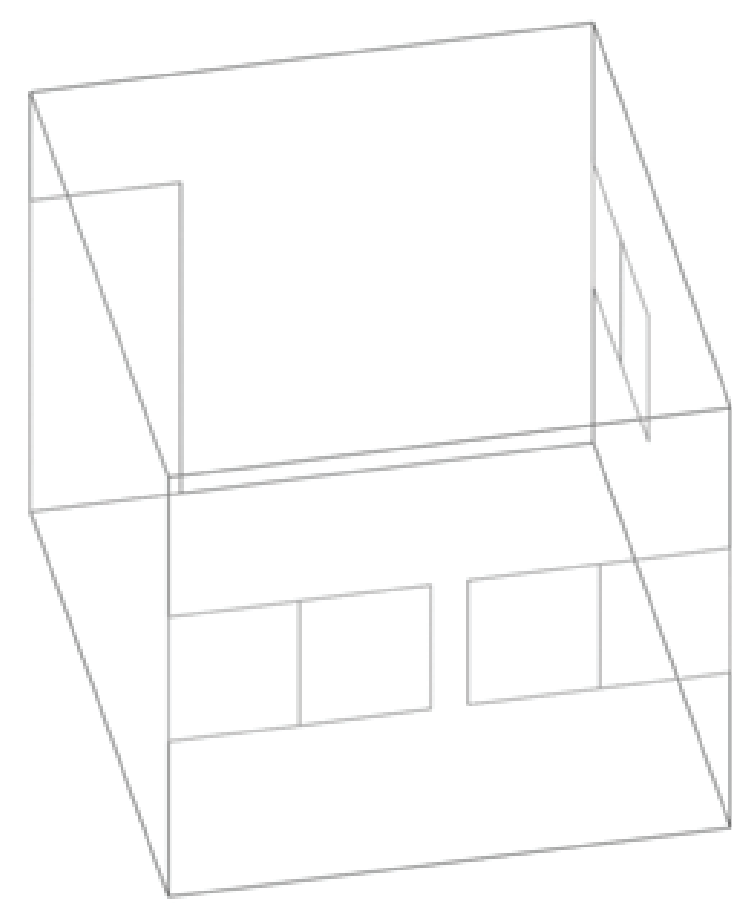

Figure 7: Basic 3D model from Revit. 


\section{Analysis}

The result from Ecotect simulation shows the shadow effect of the vertical greenery system in the thermographic pictures, can be seen in Fig. 8. First, by comparing to the bare wall model (Fig. $\mathbf{8 a}$ ) where the overheating due to solar radiation and the second for the model with vertical greenery system (Fig. $\mathbf{8 b}$ ).
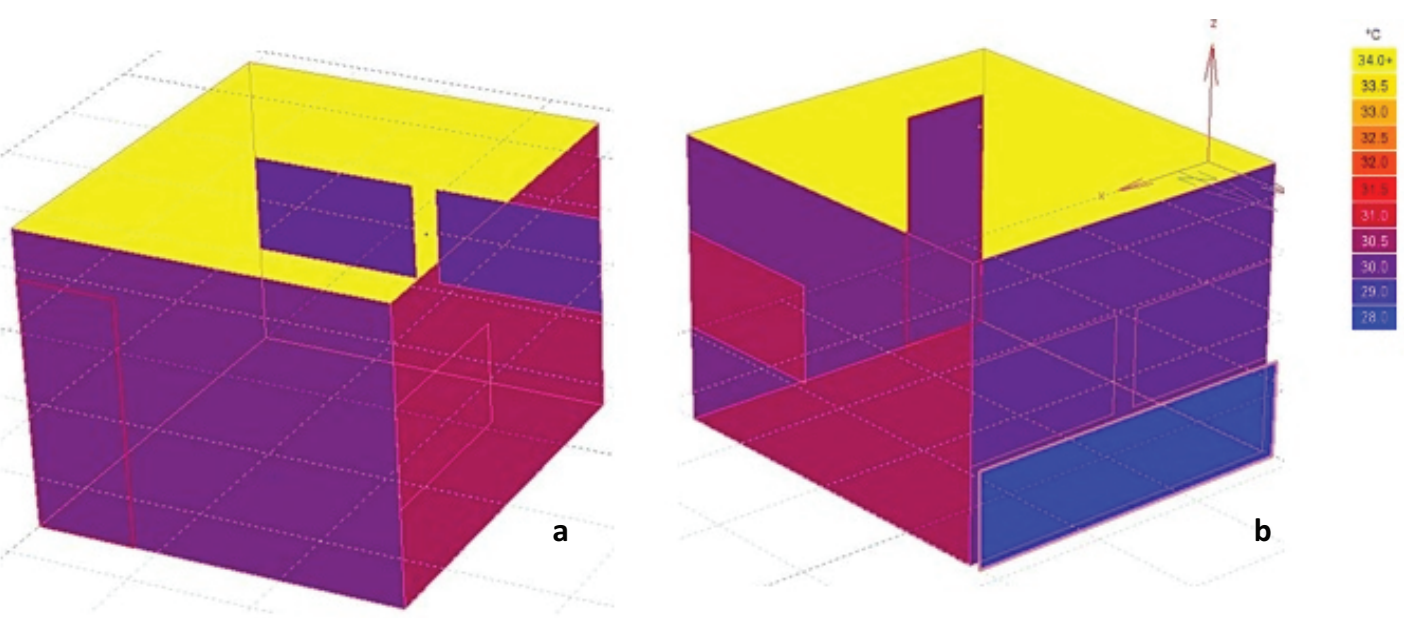

Figure 8: Ecotect simulation result on the profile of surface temperature (a). Chamber without vertical greenery system; (b) - Chamber with vertical greenery system.

In Fig. 8b, it can be seen the significant contribution of vertical greenery system to the solar radiation resulting in the high reduction on the temperature performance of building envelope compared to the chamber without vertical greenery system, can be seen in the Fig. 8a. The color of surface with vertical greenery system was blue, about at scale $28^{\circ} \mathrm{C}-29^{\circ} \mathrm{C}$ that means was cooler while the model with the bare wall was red, nearly at scale $31.5^{\circ} \mathrm{C}-32.5^{\circ} \mathrm{C}$.

Result of the simulation was compared with data from field measurement. As it was shown, simulation result fit in with the graph of data measurement where the temperature of the chamber with vertical greenery system was lower than the chamber without vertical greenery system, for surface temperatures, can be seen in Fig. 9 .

In the afternoon when outside temperatures are at their highest, vertical greenery systems have a significant effect on temperature reduction. When direct solar radiation hits the plants on the west side, cooling effect and the shade provided by the vertical greenery systems effectively reduce the temperature during the afternoon.

Based on the data measurement, the difference between the average of surface temperatures of the facade with and without vertical greenery system is $3.72^{\circ} \mathrm{C}$ for the facade with vertical greenery system and $1.51^{\circ} \mathrm{C}$ for a bare wall. 


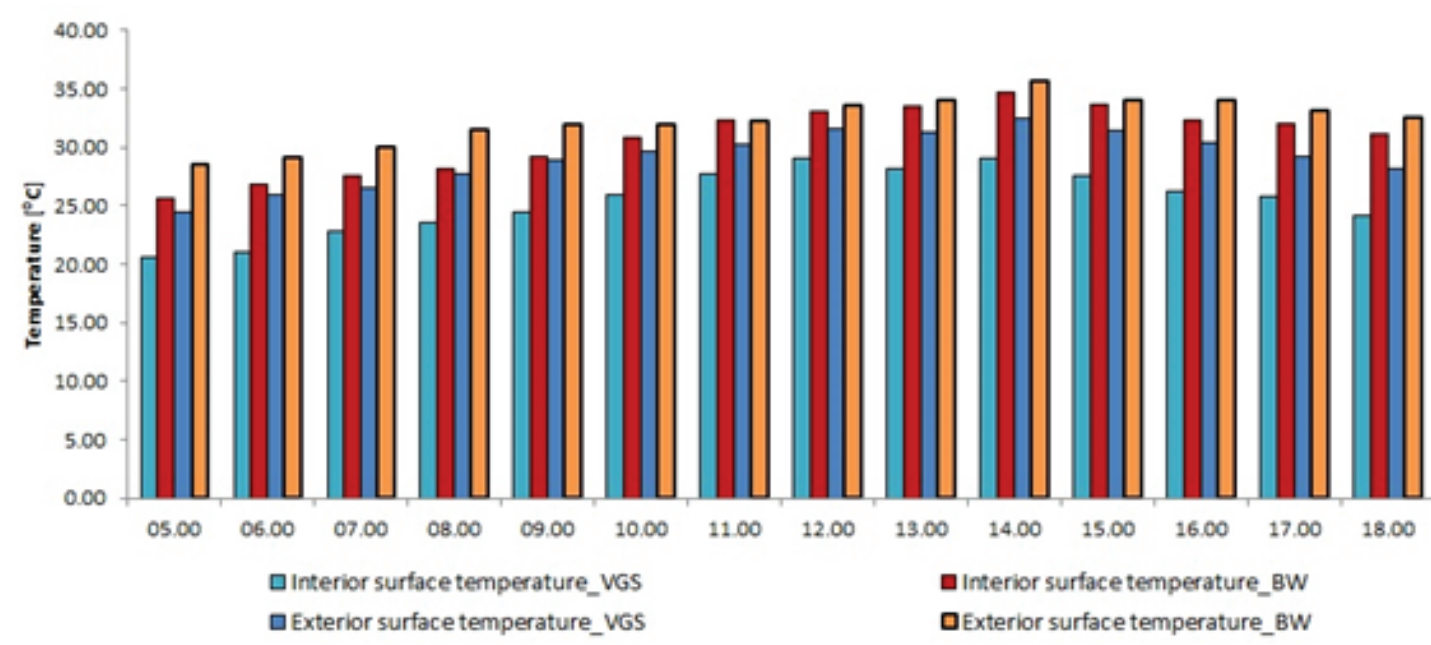

Figure 9: Surface temperature profile of the chamber with and without vertical greenery system (Note: VGS Vertical Greenery System; BW Bare Wall).

Result also shows that during data measurement, the highest temperature of the facade with the vertical greenery system reach at $29.13^{\circ} \mathrm{C}$ for exterior facade and $25.41^{\circ} \mathrm{C}$ for the interior facade. While for the facade with the bare wall are $32.30^{\circ} \mathrm{C}$ for exterior facade and $30.79^{\circ} \mathrm{C}$ for the interior facade. The differences in peak temperatures are $3.17^{\circ} \mathrm{C}$ for exterior surface and $5.38^{\circ} \mathrm{C}$ for the interior surface. The higher contrast in the facade with vertical greenery system because the gap between exterior and the interior facade is bigger. Nevertheless, results from this study proved that applying vertical greenery system on the building facade can reduce the heat transfer from the exterior facade to the interior facade. However, further analysis needs to be done to calculate the amount of heat transfer that can be reduced.

\section{Conclusion}

A continuation of long term research to study the potential of vertical greenery system as passive cooling design for energy saving, a data measurement in the facade with covered by vertical greenery system was done. The influence of vertical greenery system toward thermal performance in the building based on the Ecotect simulation analysis is the main goals in this study.

Based on the data measurement and Ecotect simulation, chamber with vertical greenery system has lower temperature and smaller in heat transfer. Respectively, the difference between the average of surface temperature on the facade with and without vertical greenery system is $3.72^{\circ} \mathrm{C}$ and $1.51^{\circ} \mathrm{C}$. Result also shows that peaks of surface temperatures on the facade with the vertical greenery system are lower $3.17^{\circ} \mathrm{C}$ 
for exterior surface and $5.38^{\circ} \mathrm{C}$ for interior surface compare to facade without vertical greenery system.

The higher difference possibility due to the bigger on the gap between exterior and interior facade. Results from this study proved that applying vertical greenery system on the building facade can reduce the heat transfer from the exterior facade to the interior facade. However, further analysis needs to be done to calculate the amount of heat transfer that can be reduced.

\section{Acknowledgment}

We gratefully thank PT. Pertamina Indonesia, branch office Semarang for giving the license to conduct this research using vertical garden application.

\section{References}

[1] Santamouris, M., Asimakopoulos, D.N., Assimakopoulos, V.D., Chrisomallidou, N., Klitsikas, N., Mangold, D., Tsangrassoulis, A. (2001). Energy and Climate in the Urban Built Environment. James \& James. London. The UK.

[2] T.R. Oke, T.R. (1982). The Energetic Basis of Urban Heat Island. Quarterly Journal of the Royal Meteorological Society, 108, 1-24.

[3] Jusuf, S.K., Wong, N.H., Hagen, E., Anggoro, R., Yan, H. (2007). The Influence of Land Use on Urban Heat Island in Singapore. Habitat International, 31, 232-242.

[4] Iqbal, I., \& Al-Homoud, M.S. (2007). Parametric Analysis of Alternative Energy Conservation Measures in An Office Building in Hot and Humid Climate. Building Environment, 42 (5), 2166-2177.

[5] Alexandri, E., \& Jones, P. (2008). Temperature Decreases in An Urban Canyon Due To Green Walls and Green Roofs in Diverse Climates. Building and Environment, 43, 480-93.

[6] Cheng, C.Y., Cheung, K.S.K., Chu, L.M. (2010). Thermal Performance of a Vegetated Cladding System on Facade Walls. Building and Environment, 45, 1779-1787.

[7] Jim, C.Y., \& He, H.M. (2011). Estimating Heat Fux Transmission of Vertical Greenery Ecosystem. Ecological Engineering, 37, 1112-1122.

[8] Taha, H. (1997). Urban Climates and Heat Islands: Albedo, Evapotranspiration, and Anthropogenic Heat. Energy and Building, 25, 99-103.

[9] Kohler, M. (2008). Green Facades-a View Back and Some Visions. Urban Ecosyst, 11, 423-436. 
[10] Onishi A., Cao X., Ito, T., Shi, F., Imura, H. (2010). Evaluating the Potential For Urban Heat-Island Mitigation by Greening Parking Lots. Urban Forestry \& Urban Greening, 9, 323-332.

[11] Eumorfopoulou, E.A., \& Kontoleon, K.J. (2009). Experimental Approach To The Contribution of Plant-Covered Walls To The Thermal Behaviour of Building Envelopes. Building and Environment, 44, 1024-1038.

[12] Holm D. (1989). Thermal improvement using leaf cover on the external walls-a simulation model. Energy and Buildings, (14), 19-30.

[13] Basher, H.S., Ahmad, S.S., Rahman, A.M.A., Qamaruz-Zaman, N. (2016). The Use of Edible Vertical Greenery System to Improve Thermal Performance in Tropical Climate. Journal Mechanical Engineering, 13 (1), 58.

[14] Liao, Z., \& Niu, J.L. (1999). Thermal Function of Ivy-Coverings on Residential Buildings. Japan: Building Simulation '99, Kyoto University.

[15] Fang, C.F. (2008). Evaluating The Thermal Reduction Effect of Plant Layers on Rooftops. Energy and Buildings, 40 (6), 1048-1052.

[16] Widiastuti, R., Prianto, E., Budi, W.S. (2016). Evaluation The Interior Façades Performance of Vertical Garden. International Journal of Architecture, Engineering, and Construction, 5 (1), 13-20.

[17] Maritime Meteorology Station of Semarang City, 2013.

[18] Semarang City Government. 2018. Peta Kota Semarang. In Bahasa

[19] https://maps.google.com/. Accessed on 17 July 2018.

[20] Bahar, Y.N., Christian Pere, C., Landrieu, J., Nicolle, C. (2013). A Thermal Simulation Tool for Building and Its Interoperability through the Building Information Modeling (BIM) Platform. Buildings, 3, 380-398.

[21] Ecotect Analysis. Sustainable Building Design Software. Available online: http://usa. autodesk.com/ecotect-analysis/ (accessed on 7 October 2018).

[22] Svetel I., Budimir N., Jarić M., (2012). BIM, MEP and Sustainability Evaluation. International Scientific Conference, Planning, Design, Construction and Renewal in the Civil Engineering, 506-512.

[23] Yin, H., Cong, Z., Ahmed, A., Tumwesigye, E., Menzel, K. Building performance analysis based on modeling and simulation. Nottingham University Press. Proceeding of the International Conference on Computing in Civil and Building Engineering. Tizani, W. (ed). 